\title{
NEW DATA ON THE DEVELOPMENT OF THE BARADLA CAVE (HUNGARY, AGGTELEK KARST)
}

\author{
NOVI PODATKI O RAZVOJU JAME BARADLA (MADŽARSKA, \\ AGTELEŠKI KRAS)
}

\author{
Veress MÁRTON ${ }^{1}$
}

\begin{abstract}
UDC 551.435.84(439)

Veress Márton: New data on the development of the Baradla Cave (Hungary, Aggtelek karst)

The development of karst landforms of the Aggtelek Plateau was investigated concerning the role of these valleys in the genesis of the Baradla Cave, which is located on the Plateau. New data were collected by geophysical method (Vertical Electrical Sounding) from a few dolines of a selected valley of the Aggtelek Plateau. The geophysical profiles confirm that the dolines of the valley bottom did not develop from sinkholes, but they are solution dolines. Morphological characteristics of the valleys of the Plateau suggest that these valleys are not the continuation of the valley of the recent covered karst. The former catchment area of these valleys might have been on the Plateau and north of Kecsö valley. Their bottoms tilted into southern direction. Therefore the subsurface capture places of their streams might have been near to the recent sinking line. The sediments (Borsodi Gravel Formation) which were eroded from the above mentioned areas also contributed to the genesis of the Baradla Cave.

Keywords: Baradla Cave, cryptokarst, sinking line, sinkhole, Aggtelek Plateau, epigenetic valley, valley with row of dolines, VES measurements.
\end{abstract}

Izvleček

UDK 551.435.84(439)

Veress Márton: Novi podatki o razvoju jame Baradla (Madžarska, Agteleški kras)

Raziskovali smo pomen rečnih dolin na razvoj jame Baradla na Agteleški planoti. Novi podatki, pridobljeni z električnim sondiranjem $\mathrm{v}$ izbranih zaprtih depresijah na dnu dolin, kažejo, da te niso nekdanji ponori, pač pa korozijske vrtače. Iz morfoloških značilnosti dolin na planoti sklepamo, da te ne predstavljajo nadaljevanja dolin današnjega pokritega krasa. Nekdanje napajalno območje teh dolin bi lahko bila sama planota oziroma območje severno od doline Kecső. Dna dolin so nagnejna na jug. Točke podzemnega odtoka voda teh dolin so bile verjetno $\mathrm{v}$ bližini današnje linije ponorov. Pomembno vlogo v razvoju jame Baradla, so verjetno imeli tudi sedimenti gruščnate formacije Borsodi, erodirani nad obravnavanim območjem.

Ključne besede: Jama Baradla, kriptokras (skriti kras), ponorna črta, vrtača, Agteleška planota, epigenetske doline, doline z nizom vrtač, električno sondiranje.

\section{INTRODUCTION}

In this paper we present the evolution of the valleys of Aggtelek Plateau, furthermore we analyse the role of these valleys in the karstification of the Plateau and the development of the Baradla Cave. The Plateau is between the Aggtelek-Jósvafö highway and Kecső Valley (Fig. 1).
The Aggtelek karst was described by Hevesi (1989), the Baradla Cave was described by Takácsné Bolner et al. (1989) in English. The Plateau belongs to Aggtelek Mountain, which is part of the Gömör-Tornai karst. The Hungarian part of this karst is called Aggtelek-Rud-

${ }^{1}$ University of West Hungary, Faculty of Natural Sciences, Karoly Gáspár tér 4, Szombately, Hungary, e-mail: vmarton@ttk.nyme.hu Received/Prejeto: 5.7.2011 
abánya Mountains, which includes two karst areas: the Aggtelek Mountain (or Aggtelek karst) and Alsó-hegy (Lower Hill). Its Slovak part is termed the South-Slovak karst (Figs. 1 \& 2).
According to Láng (1955) four morphological horizons can be distinguished on the Plateau which have different altitudes: 1 . on the west there is a doline horizon at the altitude of 450-500 metres, on the east there are
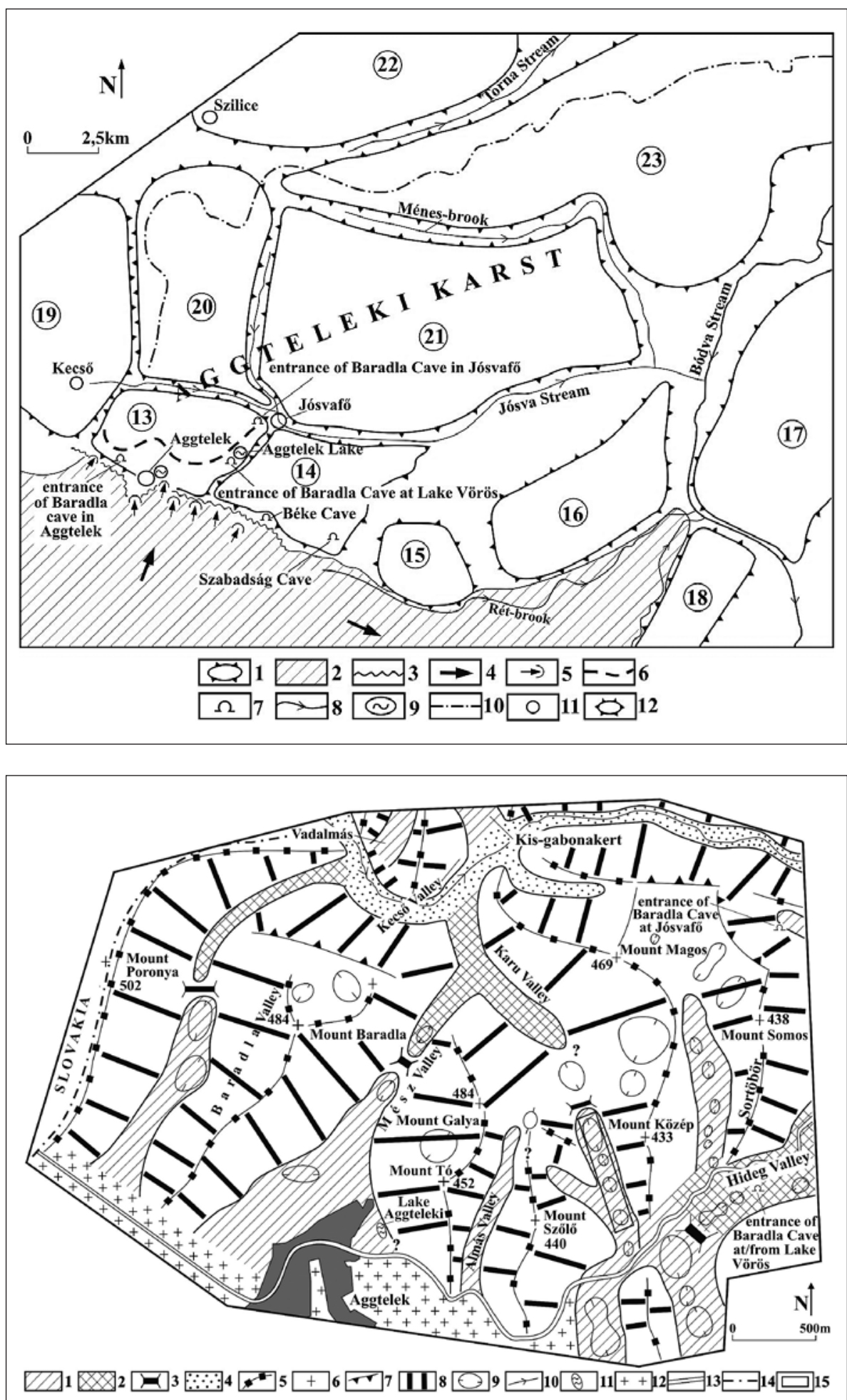

Fig. 1: The Gömör-Tornai karst and the sinking line.

Legend: 1. karst plateau, 2. cryptokarst, 3. sinking line, 4. tilt direction of cryptokarst, 5. sinkhole, 6. site of Baradla Cave (approximately), 7. cave entrance, 8. stream, 9. lake, 10. frontier, 11. village, 12. Plateous, 13. Aggtelek Plateau, 14. Pitics Mount, 15. Teresztenye Plateau, 16. Eastern part of $\mathrm{Ga}$ lyaság, 17. Szalonna Mountains, 18. Rudabánya Mountains, 19. Kecsö Plateau, 20. Haragistya Plateau, 21. Szinpetri Plateau, 22. Szilice Plateau, 23. Alsóhegy (Lower Hill).

Fig. 2: The Aggtelek Plateau.

Legend: 1. bottoms of older valley and the bottoms of tributaries of the older valley, 2. bottom of the tributary valley which developed on the floor of the older valley by the headward erosion of the Kecsö and Jósva, 3. valleyfloor divide (saddle), 4. bottom of the Kecsö and its tributary valley (which did not develop at older valley bottom), 5. ridge, 6. mound (hum), 7. the margin of the Kecsö Valley, 8. Valley side, 9. doline, 10. stream, 11. lake, 12. cryptokarst, 13. road, 14. frontier, 15. valley bottom with VES measurement sites. 


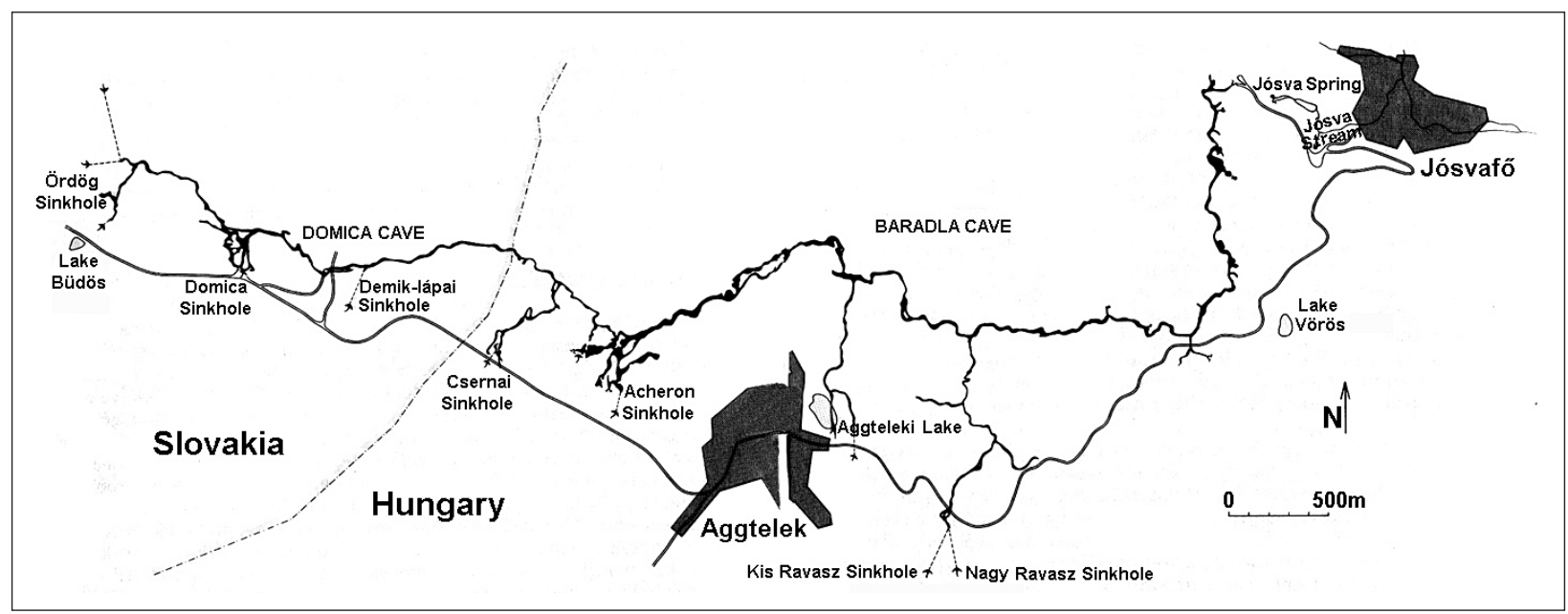

Fig. 3: The Baradla Cave (Source: Kordos 1984).

mounds without dolines, 2. several planar surfaces with dolines at altitudes of 350-450 metres, 3. non-limestone horizon at altitudes of 300-350 metres, 4 . non-limestone surface at altitudes of 250-280 metres.

The number and size of caves of the Aggtelek karst are great (for example such large-sized caves are the Baradla Cave, Szabadság Cave, Imre Vass Cave, Kossuth Cave, Béke Cave etc.). The Baradla Cave is the longest and the most important of them (Fig. 3): its length is 25-30 km. It includes a main corridor and its connecting tributary passages. Sinkholes are connected to the tributary corridors which carry the water of the cryptokarst situated south of the Aggtelek Plateau. Its great size is due to the ponors and the large catchment area which is on the cryptokarst south from the cave.

Many karst researchers investigated the cave: for example Vass (1831), Dudich (1930, 1932), Konrád (1930), Maucha (1930), Kessler (1933, 1938, 1939), Cholnoky (1935), Jaskó (1935), Jakucs (1952, 1956a, 1956b, 1959, 1960, 1977), Wagner (1965), Szentes (1965), Szenthe (1970), Lauritzen-Leél-Össy (1994), Zámbó et al. (2002), Bosák et al. (2004), Berényi et al. (2006), Veress (2008). Cholnoky (1935) interpreted the development of the Baradla Cave as it was created by mechanical erosion processes, due to waters and deposits coming from the bordering cryptokarst. Jakucs described the development model of this type of erosion cave and its morphological characteristics during the investigation of the Baradla Cave (Jakucs 1956a, 1977). According to Jakucs (1956a) the sediments (mainly gravel), which were transported trough the sinkholes, caused the erosion enlargement of the cave. This process favoured the creation of large corridors.

The Aggtelek karst is mainly made up of Upper and Lower Triassic limestone and dolomite, while its covering deposits are Miocene sands and clays and
Pliocene gravels. The mountain has a nappe structure (Less 1998) and has been dismembered into horsts during its uplift. The horsts and horsts group appear as karstic plateaus.

The Aggtelek Plateau and its surroundings were described as a type of allogenic karst by Jakucs (1956a). His study has great importance and it is a classical work. He distinguished phase I and phase II during the karstic development of the plateau. Phase I is of Upper-Miocene (Pannonian) Age. Then the streams of the Upper-Miocene surface which reached the Kecső and Jósva Valleys, had created the Baradla, Mész and Hideg Valleys by this time because they were already epigenetic valleys. The valleys were transformed into doline-row valleys without water flow during phase II. Namely the sinkholes which developed at the sinking line drained the seasonal streams which are on non karstic rock surface of the cryptokarst into the Baradla Cave (Fig. 1). The author only suggests that sinkholes developed on the former valley junction in the case of doline-row valleys. Later the development of the sinkholes moved to southern direction to the recent sinking line because of the recession of the junctions of the valley. Therefore the older sinkholes which had northern direction of prevailing sinking line, changed into dolines (Fig. 4). This theory was proposed to explain the development of doline-row valleys at the Aggtelek karst and the Bükk Mountain (Hevesi 1978, 1980; Móga 2002a).

We would like to mention that the number of the valleys, or valley-like forms, is greater than mentioned above. Zámbó (1998) described 14 doline-row valleys on the Plateau, which are presently dry valleys. They can be trunk or tributary valleys. Some of them (such as the shortest ones) developed due to solution, but the shape and the size of the longer valleys could be changed mainly through solution. 
The karst genetic investigations were extended to other plateaus of the Aggtelek karst (the Slovak karst

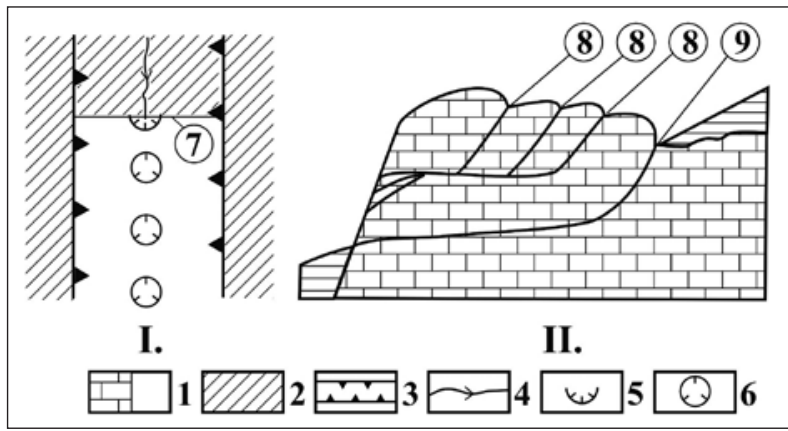

Fig. 4: Development of doline row valley during recession of subsurface capture (based on Jakucs 1977; Hevesi 1985).

Legend: I. planimetric representation, II. profile, 1. limestone, 2. non-karstic rock, 3. valley, 4. stream, 5. sinkhole, 6. doline, 7. valley-floor divide, 8. fossil sinkhole (doline), 9. active sinkhole. which is a part of the Gömör-Torna karst). These investigations show that the development of the various karst plateaus was independent and different from other plateaus. On those plateaus which were covered (from example Szilice Plateau, Derenk Plateau) the valleys cut into the superficial deposit inherited from the cover on the limestone (Móga 1999, 2002b). Sinkholes developed during epigenetic processes. The valleys changed into doline-row valleys because of the recession of the sinking point (Móga 1999).

Other plateaus are autogenetic karst type (for example Szilas Plateau, the Haragistya, Móga 2001, 2002b). There are plateaus which are allogenic karsts (for example Kecsö Plateau). There the karstic rock lies in lateral contact with non-karstic rock (Móga 2001). But there are plateaus whose lower margins are covered (Teresztenye Plateau). Autogenic karstification happened on their higher parts but doline-row valleys developed along their margins (Móga 2002a).

\section{METHOD}

Karst can be studied using geophysical methods, including seismic, electric conduction VES measuring, multielectrode sounding, electromagnetic, (frequency domain electromagnetic), radar (ground penetrating radar) and gravity methods (Hoover 2003). Vertical Electrical Soundings (VES) was employed by us to research the morphology and depth of the bedrock (limestone), and the stratigraphy and the thickness of the superficial deposit (Veress 2009).

We could calculate stratigraphic columns for all sites along the measurement lines. If the columns are as- sembled along the measurement lines then we can obtain profiles (geoelectrical geological cross-section). The profile of the surface (with covered karst depressions), bedrock, bed boundaries, (and so the various superficial deposits), the structure of the superficial deposit and the resistance value of the various rocks can be shown in the cross-sections. We can establish the profile of the surface of the bedrock more exactly where limestone is exposed.

\section{RESULT OF THE INVESTIGATION OF THE VALLEY BETWEEN SZÖLŐ MOUNT AND KÖZÉP MOUNT}

A N-S doline-row occurs on the bottom of the investigated valley. The northern and southern slopes of the dolines are gentle, while the eastern and western slopes are steep. The shapes of dolines are controlled by the valley, the longer axis of the dolines coinciding with that of the valleys. The side of the valley deterred the development of the dolines. The bottoms of dolines are gently sloping, nearly planar. Residual bottoms with different altitudes and width are among the dolines (Fig. 5).
We can establish the following statements from the results of the investigation (Figs. 6-8).

- The sediment fill of dolines is not considerable (its thickness is between 2-10 meters) with respect to the extension of dolines (their diameters are between 50-200 meters, their depths are several tens of meters).

- The doline sediment fill consists of clay and limestone debris. The limestone debris might have developed in the same place. Debris border the clay patches from 


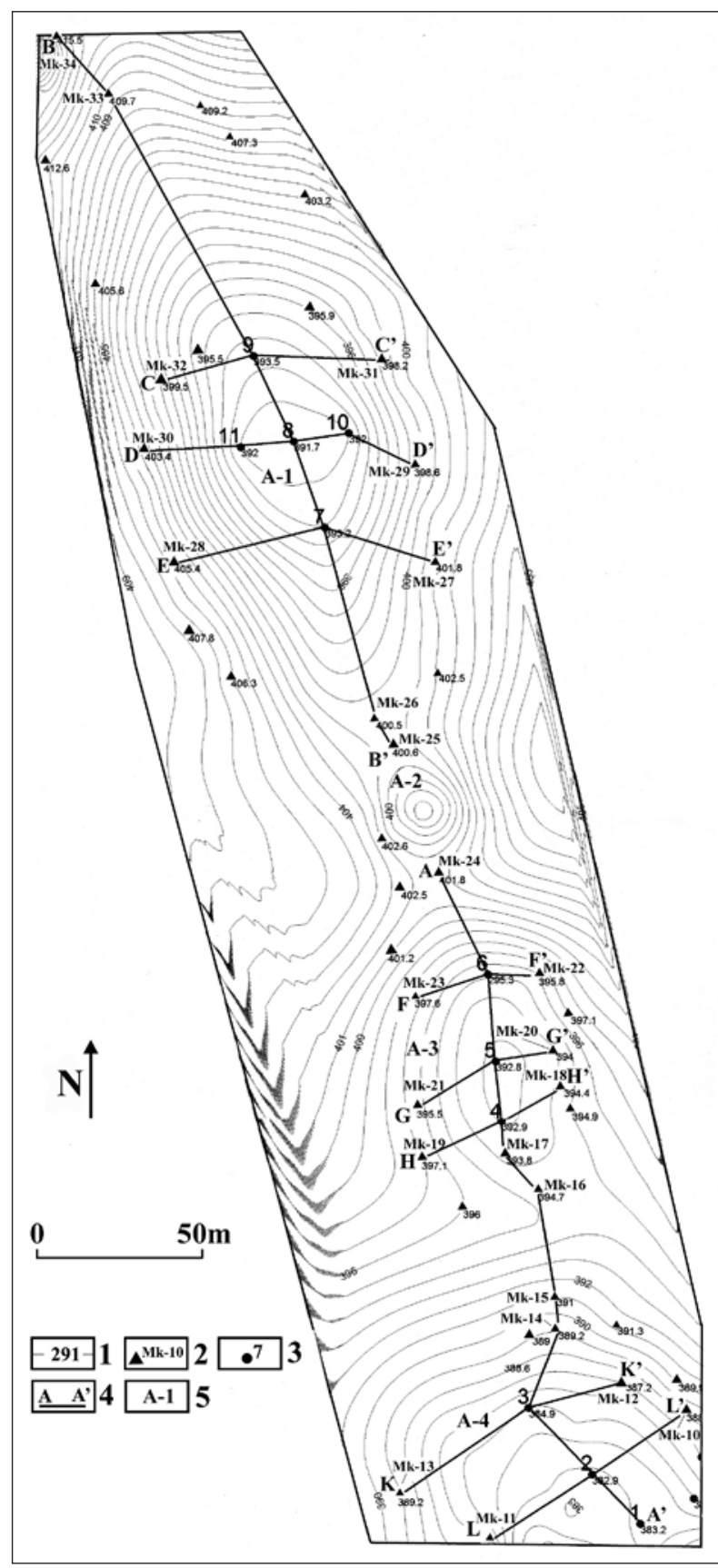

Fig. 5: The topographic map of one part of the investigated valley (After: Veress 2008).

Legend: 1. contour line, 2. identification number of limestone outcrop, 3. site of VES measurement with identification number, 4. line of profile, 5. mark of karstic form. the north and the south, therefore the clay could not be transported from either directions. The fact proves that fluvial sediment could not be transported into the dolines neither from northern nor from southern directions.

- These dolines did not form from ponors because there is no fluvial sediment in the dolines.

- The sediment of dolines locally has a lenticular attitude. Therefore they developed locally. If fluvial transportation had happened then the beds should be elongated and have a northern-southern inclination. Such sediment structure is created if a sinkhole fills up, as in the area of the Keserü-tó lápa (Teresztenye Plateau, Figs. 9-10).

Therefore we established that sinkholes did not develop on the surveyed valley section. There are no dolines, but there is an uvala on the bottom of the valley. The data of the geophysical investigation were obtained from lime kilns located in the northeast inner part of a doline. Hence the limestone or limestone debris is near the surface, hence the planar bottom of the dolines might not develop due to infilling. It can imply that the bedrock surface is also flat or with a gentle slope. This bedrock morphology developed during lateral solution and it rules out the fact the dolines might develop from sinkholes.

Further data prove that subsurface capture did not occur on the bottoms of the epigenetic valleys of the Aggtelek Plateau. These data are the following:

- The karstic depression system which occurs at the entrance of the Baradla Valley, is a typical uvala; its depressions are not former sinkholes, but there are solution dolines. The dolines developed due to lateral solution and were transformed into an uvala.

- The Baradla Cave has no erosional tributary caves which lead from northeast direction to the cave. Hence streams did not flow into the cave from the surface to the valley bottom sections to the northeast of the Baradla Cave. Therefore sinkholes did not develop on valley sections northeast of the Baradla Cave. 

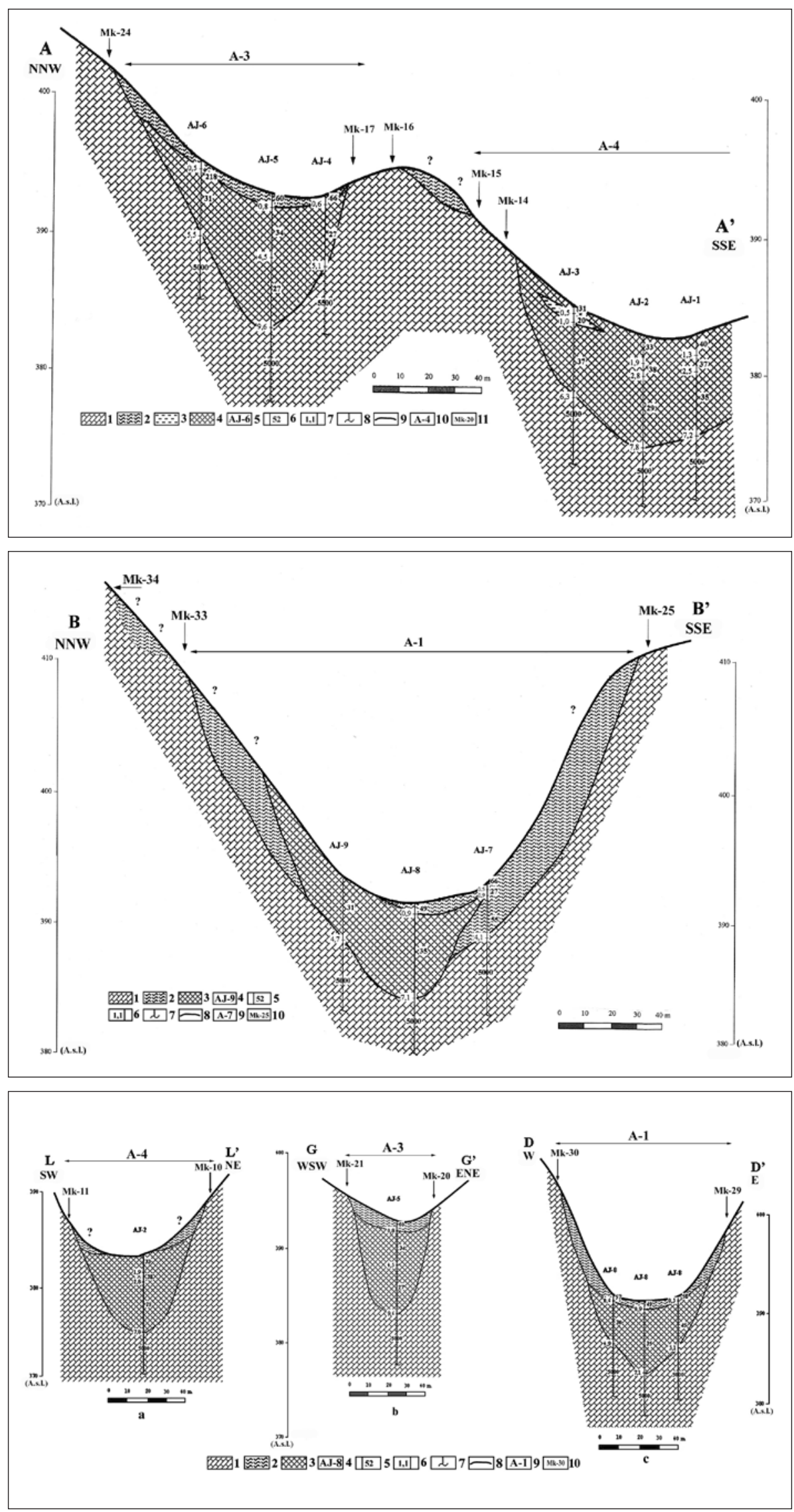

Fig. 6: Geoelectrical-geological profile marked A-A' (After: Veress 2008).

Legend: 1. limestone, 2. limestone detritus (with clay), 3. clay, 4. clay (with limestone detritus, with sand), 5. site of the VES measurement with identification number, 6. the geoelectrical resistance of the beds (Ohm), 7. depth of bottom of the geoelectrical beds $(m)$, 8. the approximate penetration of VES measurement, 9. boundary of geoelectric beds, 10. the mark of the karstic form, 11. outcrop, with identification number.

Fig. 7: Geoelectrical-geological profile marked B-B' (After: Veress 2008).

Legend: 1. limestone, 2. limestone debris (with clay), 3. clay (with limestone debris, with sand), 4. site of the VES measurement with identification number, 5. the geoelectrical resistance of the beds $(\mathrm{Ohm}), 6$. depth of bottom of the geoelectrical beds $(m), 7$. the approximate penetration of VES measuring, 8. boundary of geoelectrical beds, 9. the mark of the karstic form, 10. outcrop, with identification number.

Fig. 8: Geoelectrical-geological profiles marked the $L-L^{\prime}(a)$, the G-G' (b) and the D-D' (c) (After: Veress 2008).

Legend: 1. limestone, 2. limestone detritus (with clay), 3. clay (with limestone detritus, with sand), 4. site of the VES measurement with identification number, 5. the geoelectrical resistance of beds (Ohm), 6. depth of bottom of the geoelectrical beds (m), 7 . the approximate penetration of VES measuring, 8. boundary of geoelectrical beds, 9. the mark of the karstic form, 10. outcrop with identification number. 

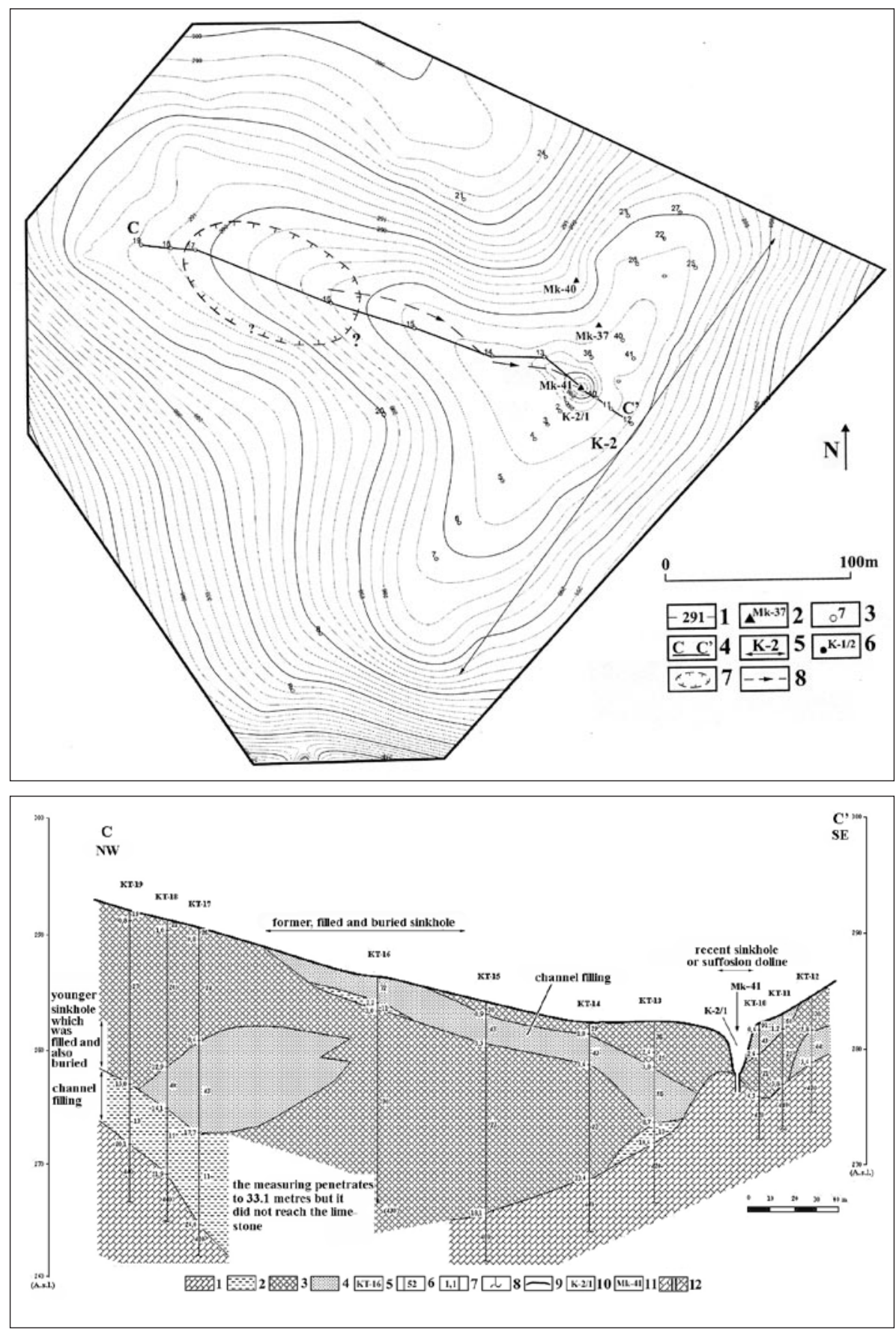

Fig. 9: Part of the Keserü-tó depression (After: Veress 2008).

Legend: 1. contour line, 2. outrop with identification number, 3. site of VES measurement with identification number, 4. profile line, 5. partly exhumed doline or uvala, 6. the identification number of the karstic form (sinkhole), 7. filled and buried sinkhole, 8 . channel.

Fig. 10: Area of depression of Keserü-tó (K-1) of geoelectricalgeological profile marked $C-C^{\prime}$ (After: Veress 2008).

Legend: 1. limestone, 2. clay, 3. clay (with limestone detritus, with sand), 4. sand-gravel-loess (with limestone detritus), 5. site of the VES measurement with identification number, 6. the geoelectrical resistance of the beds $(\mathrm{Ohm}), 7$. depth of bottom of the geoelectrical beds $(m), 8$. the approximate penetration of VES measurement, 9. boundary of geoelectrical beds, 10. the mark of the karstic form, 11. outcrop, with identification number, 12. shaft.

\section{THE DEVELOPMENT OF THE VALLEYS OF THE AGGTELEK PLATEAU}

The uppermost Miocene deposits (Edelényi Formation) developed in lake, swamp and fluvial environments (Less 1998). Its border is concordant in the research area with the border of the recent deposition (Sásdi 1990). The Aggtelek karst was tilted in the Pliocene-Pleistocene bound- ary to southern, southern-eastern direction (Sásdi 1990). Therefore gravel was transported (Borsodi Gravel Formation) from the Slovak Ore Mountains (Móga 2002a) to bare surfaces and also to the Upper-Miocene surfaces (Sásdi 1990). The mountains were dismembered into 
blocks in the Pleistocene and Holocene, and the blocks underwent uplifting, tilting or horizontal slip-sliding to various degrees. The uplift of Aggtelek Plateau was the most intensive in the western and southern parts. Therefore, the surface of the Aggtelek Plateau (but also the bordering cryptokarst) tilts from southern to eastern directions (Sásdi 1990; Zámbó 1998).

Valley development began on the former surface of the Plateau covered and tilted to SSE (Baradla, Mész and Hideg Valleys, along with the tributary valley of the latter one). These valleys, which could be epigenetic to the limestone, retreated from south to north. They did not retreat from north to south, therefore the surface dipped into SSE direction. This process is proved by the following:

- The bottoms of few valleys descend from north to south. The steepness of the former slope might have been greater but the uplift of the southern part of the Plateau was greater than in the northeast part. Therefore the rate of the uplift of the valley bottom decreased.

- The northeast end of a few valleys form a valley head (for example Sortöbör Valley, Almás Valley, Fig. 1). Such valleys might have developed if they retreated from north to south. Such recessional valley development may occur if the surface tilts from north to south.

- Other southern sections of valleys descend to south direction, while their northernmost sections tilt to the north (Fig. 1). It may be possible, although the valleys tilted to the south along their whole lengths but because the Kecsö and the Jósva streams developed, the original tilting direction of the valleys changed to the opposite (to the north). During the process a valley-floor divide might have developed. For example such valleys are Baradla Valley and the Mész Valley concerning the valleys which were investigated by us. The Karu Valley is an extreme case of the northeast direction recession. Because of development of the Kecső Valley, the recession of the Karu Valley, which is the tributary of the Kecsö Valley, happened very intensively. Therefore the Karu Valley destroyed the northeast bottom parts of the Mész Valley and the valley under study. Further during the process the Karu Valley detached the catchment area of these valley.

- The investigated tributary valley could not have developed along the recent dip direction of the Plateau. The gradient of the tributary valley, which is the opposite of the direction of the Hideg Valley, could be obtained when the bearing surface had a dip direction opposite of that of today (Fig. 11).

Therefore, these valleys are not the continuations of the valleys of the cryptokarst. However, probably some valleys (Baradla-, Mész Valley) developed north of the Kecső Valley, too. Because of the incision of the Kecső
Valley these valleys lost important parts of their catchment areas. The Mész Valley continues in the so-called Kis Gabona kert which is north of the Kecső Valley. The valley which is situated at Vadalmás can be the continuation of the Baradla Valley, north of the Kecső Valley.

The above mentioned process (the surface suffered subsurface capture of these valleys by the Jósva stream) might take place because the development of the Kecsö Valley happened later than the development of the valleys of the Plateau in the north-south direction between the villages Jósva and Kecső. It was possible, because the headward erosion of the Kecsö was slower on the Plateau whose dip direction is southern, than the valleys of the

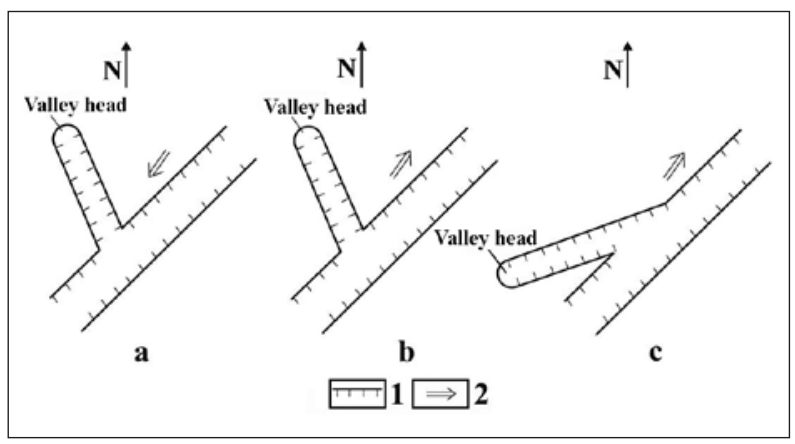

Fig. 11: The dip direction of the surface of the Hideg Valley and the investigated tributary valley (a), the today direction dip (b), the probable development direction of the tributary, if the dip direction of surface might have been concordant with that of today in the time of its development (c).

Legend: 1. valley margin, 2. dip direction of bearing surface.

Plateau oriented along the north-south line. The rate of headward erosion for the Kecsö Valley accelerated when the Plateau tilted to northern and eastern directions (Pleistocene to Holocene) and the valley might have reached the surface between Jósva and Kecső villages.

The valleys of Aggtelek Plateau might have developed independently and earlier than the valleys to south of the sinking line. This explains why the valley of the Aggtelek Plateau are larger (mainly the deeper valleys) than the valleys of the cryptokarst. These valleys might have been larger before (the valley sections have been incised into the bedrock). Further evidence is that the valleys of the Plateau are older than the valleys of the cryptokarst because they are cut into the limestone and the development of a similar valley size in the limestone needs longer time than in non-karstic rock since the rate of valley development is lower in this rock.

Valleys south of the sinking line developed when the bearing surface dipped to northern and eastern directions. (It is unknown when the dip direction changed). Namely the continuations of the valleys of the Aggtelek 
Plateau are not present on the cryptokarst. The recent valleys of the cryptokarst are blind valleys and their bottoms show a northern gradient. All the bottoms of the valleys (Baradla, Mész, Hideg Valleys) of the bare karst have a southern slope direction, their size is greater than that of the valleys on the cryptokarst, furthermore their size decreases towards the north. If the valleys of the cryptokarst are the continuations of the valleys of the Aggtelek Plateau, then on the upper part of valleys counterslope sections may occur, they should have developed when the bearing surface had a southern gradient.

Two processes contributed to the northern gradient of the cryptokarst surface south of the Aggtelek Plateau: the uplift of the area and slope development. The slope development may be explained by the denudation of the superficial deposits which were transported into the $\mathrm{Ba}$ radla Valley through sinkholes. We can prove the uplift of the bearing surface by the Upper-Miocene sediment which is at 300 metres a.s.l. on the margin of the Teresztenye Plateau (Sásdi 1990).

The drainage divide (Kovacsos Mount, Kerekerdö) of the cryptokarst is not crossed by valleys. The valleys of the Plateau (Baradla Valley, Mész Valley, Hideg Valley) all terminate at the northern drainage divide. Gravels which overlie the Upper-Miocene deposits may have been accumulated partly by the streams of the above mentioned valleys. These valleys might have wedged out or suffered subsurface capture where a limestone outcrop occurred.
So-called primarily generation sinkholes developed in these sites (at the former junction). The highest probability of their development is observed near the recent sinking line. The surface of the limestone was deeper north of the sinking line while the valleys were not inherited onto the limestone (Fig. 12c). We believe that subsurface capture was prevented by several conditions north of the sinking line. These valley sections lost their catchment area as well as their streams because of the tilted uplift in the Pleistocene and Holocene. The headward erosion of the Kecső Valley and the subsurface capture connected to the process reduced the catchment area (through surface and subsurface captures.) Less and less water recharged the valleys from these surfaces due to the removal of the superficial deposit. The Aggtelek Lake might have been the site of a former subsurface capture, the former sinkhole of the Mész Valley. The remnants of the lime kilns, the dolines of the Mész Valleys, prove that doline fills are thin. Hence the bottoms of dolines are flat or very gently sloping, also developed by solution.

Former covered karst surfaces which occur north of the cave contributed to the erosional development of the Baradla Cave. Probably the former cryptokarst contributed to the development of the major cave. The erosion development could have taken longer than described by Jakucs (1956). If we take the former gravel cover of the surface also into account, more quartz gravels were available for the erosional development of the cave.

\section{DEVELOPMENT HISTORY}

- Karstification begins on uncovered bedrock. The paleocave system of the Baradla developed under the karst water table (Fig. 12a), because according to Láng (1955) the karst water table was near the surface in the Miocene and Pliocene. The reasons for this were that the karst water table (Láng 1955) rose because of the sediment accumulation in the Upper-Miocene basins (Sásdi 1990).

- The Aggtelek Plateau tilted, the gravel cover developed on the surface of the SSE dip direction of the plateau (Fig. 12b).

- The plateau was uplifted. With N-S direction valleys of the plateau developed by headward erosion. Sinkholes developed close to the sinking line (first generation sinkholes). The Baradla Cave developed due to erosion (Fig. 12c).

- Another tilting phase followed. The southern part of plateau was uplifted. The gradient of the valley bot- toms decreased. Karstification began on the bottoms of valleys of the plateau (dolines, uvalas developed). Because the Kecsö Valley developed some valleys suffered subsurface capture. Erosional-corrosional tributary valleys developed by headward erosion from the Kecső and Jósfa on the valley bottoms. The erosional development was slowed down or stopped in case of the Baradla Valley. The passages were filled up (Berényi et al. 2006, Fig. 12d).

- The tilting continued. The dipping of the surface changed to its opposite. Sinkholes developed along the sinking line and are still active today (second generation sinkholes). The valleys were formed on the present-day cryptokarst and developed by headward erosion to the south of the sinkholes. Sediments were carried in from the passages of the Baradla cave. The erosion development can be renewed (Fig. 12e). 


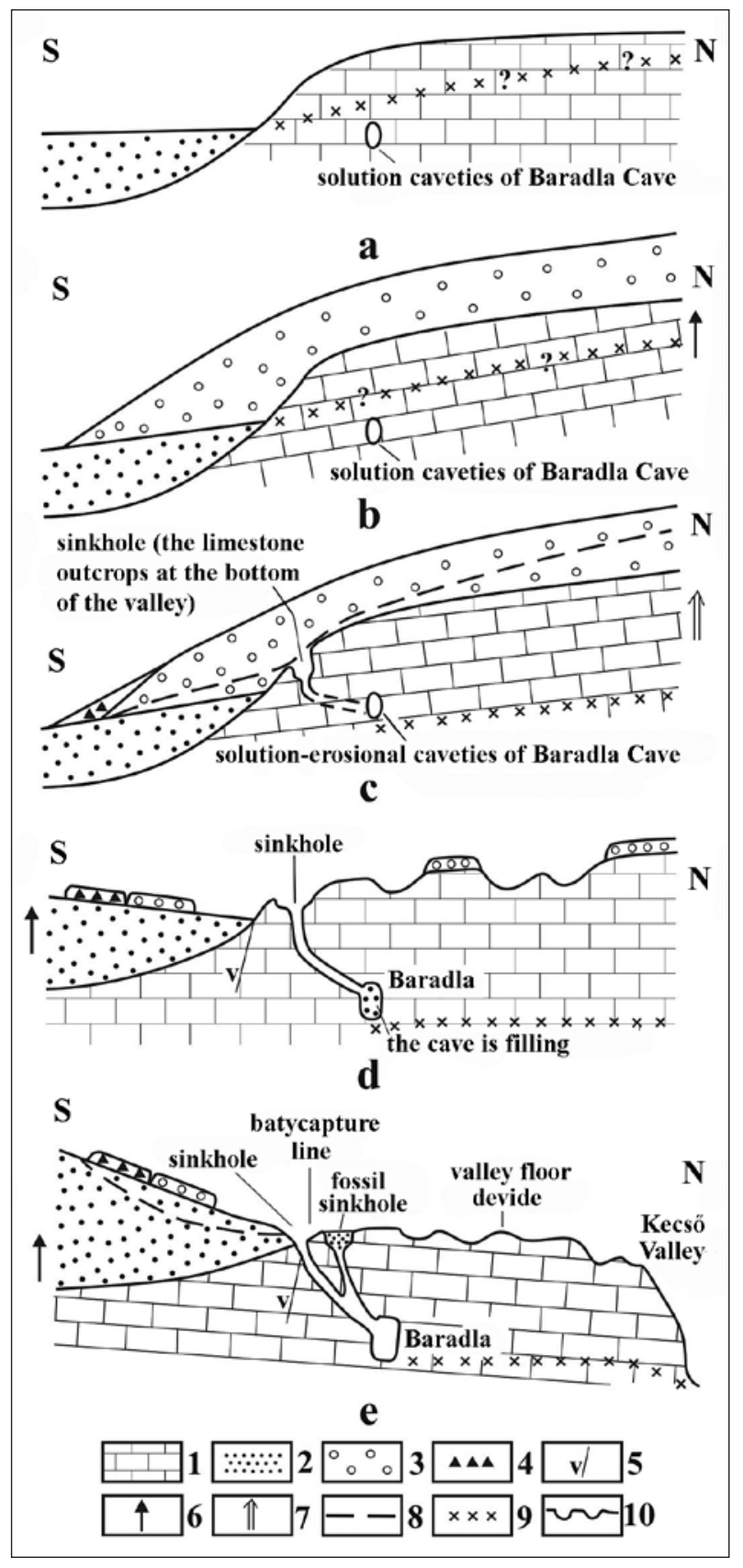

Fig. 12: Surface and valley development on the Aggtelek Plateau. Legend: a. Upper Upper-Miocene: the Aggtelek Plateau is bare karst, the beds of Edelényi Formation developed south of plateau, $b$. Pliocene-Pleistocene: the plateau tilted, its surface sloped to SSE, and also the cryptokarst are covered by the Borsodi Gravel Formation, c. Pleistocene (?): the plateau is uplifted, valley development started in its area, sinkholes (first generation sinkholes) developed where the valleys reached the limestone and the karst water table sank deepen regard to valley bottom, $d$. Pleistocene (?): South of the plateau margin the present-day cryptokarst area uplifted, the surface of the plateau can be almost flat, the valleys inherited onto the limestone along their whole length, solution dolines developed on the valley bottom, e. Upper Pleistocene and Holocene: the tilting continues, the surface of the plateau slope to the north, a second generation of sinkholes developed along the margins, 1. limestone, 2. gravel, sand, clay (Edelényi Formation), 3. gravel (Borsodi Gravel Formation), 4. resedimented gravel, 5. fault, 6. tilt, 7. uplift, 8. valley bottom, 9. karst water table, 10. dolines and uvalas.

\section{CONCLUSIONS}

The valleys of Aggtelek Plateau are not the continuation of the valleys of the recent cryptokarst. The development of the valleys of the plateau happened earlier than the development of the valleys of the present-day cryptokarst. Valleys of the plateau developed when the surface of Aggtelek karst dipped to the SSE. Sinkholes did not develop in the valleys. Subsurface capture might happen along the recent sinking line. Two generations of sinkholes developed along this line. Streams which came from the northern part of the karst contributed to the development of the Baradla Cave. Stream erosion generated cave development may happen if we know the age of the tilting to the SSE direction (which is Pliocene-Pleistocene) even if the process was not continuous. 


\section{AKNOWLEDGEMENTS}

The study was carried out with the financial support of the TÁMOP-4.2.1/B-09/1/KONV-2010-0006 Project.

\section{REFERENCES}

Berényi Üveges I., Berényi Üveges J. \& G. Vid, 2006: Adalékok a Baradla-barlang fejlődésének elméletéhez üledékvizsgálatok alapján (Some data to the theory of evolution of the Baradla Cave by using sediment investigations).- Karszt és Barlang, I-II, $33-40$.

Bosák, P., Herman, H., Kadlec, J., Móga J. \& P. Pruner, 2004: Paleomagnetic and U-series Dating of Cave Sediments in the Baradla Cave Hungary.- Acta Carsologica, 33, 2, 219-238.

Cholnoky, J., 1935: Az Aggteleki Baradla-cseppköbarlang története (History of the Baradla dripstone cave of Aggtelek) 113-125.- Égen, földön (Földrajzi Értekezések), pp.197, Budapest.

Dudich, E., 1930: Az Aggteleki barlang vizeiröl (About the waters of Aggtelek Cave).- Hidr. Közl., 1-33.

Dudich, E., 1932: Az Aggteleki cseppköbarlang és környéke (The Aggtelek dripstone cave and its environment).Kir. Magy. Term.Tud. Tás., pp. 186, Budapest.

Hevesi, A., 1978: A Bükk szerkezet- és felszínfejlődésének vázlata (Sketch of the structural and geomorphic evolution of Bükk Mountains).- Földr. Ért., 27, 2, 169-203.

Hevesi, A., 1980: Adatok a Bükk-hegység negyedidőszaki ösföldrajzi képéhez (Some data to the Quaternary palaeogeographic picture of Bükk Mountains).Földt. Közl., 110, 3-4, 540-550.

Hevesi, A., 1985: Development and evolution of karst regions in Hungary.- Karszt és Barlang, Special Issue, 3-16.

Hoover, R.A., 2003: Geophysical choices for karst investigations - www.saic.com/geophysics/downloads/ karstChoices.pdf

Jakucs, L., 1952: Aggteleki-cseppköbarlang (The Aggtelek dripstone cave).- Művelt Nép, pp. 126, Budapest.

Jakucs, L., 1956a: Adatok az Aggteleki hegység és barlangjainak morfogenetikájához (Some data to the morphogenetics of the mountains and caves of $\mathrm{Ag}$ gtelek).- Földr. Közl., 2, 25-35.

Jakucs, L., 1956b: A barlangi árvizekről (About cave floods).- Földr. Közl. 4, 281-303.
Jakucs, L., 1959: Felfedezö utakon a föld alatt (Discovery trips under the ground).- Gondolat Könyvkiadó, pp. 253, Budapest.

Jakucs, L., 1960: Az aggteleki barlangok genetikája a komplex forrásvizsgálatok tükrében (Genetics of Aggtelek cave-system by a complex water test).Karszt és Barlangkutatás, I, 37-66.

Jakucs, L., 1977: A magyarországi karsztok fejlődéstörténeti típusai (Genetic types of the Hungarian Karst).- Karszt és Barlang, I-II, 1-16.

Jaskó, S., 1935: A Baradla-barlang jósvafői szakaszának karszthidrológiája (Karst hidrology of Jósvafö part of the Baradla Cave).- Hidr. Közl., XV, 196-204.

Kessler, H., 1933: Ujabb kutatások a Nagy-Baradlában (Newer researches in the Nagy-Baradla).- Turistaság és Alpinizmus, XIII, pp. 239.

Kessler, H., 1938: Az aggteleki barlangrendszer hidrográfiája (The hydrography of Aggtelek cave system).- Földr. Közl. LXVI, 1-30.

Kessler, H., 1939: Az aggteleki cseppkőbarlang (The Aggtelek dripstone cav.- Földr. Ért., IV, 17-26.

Konrád, Ö., 1936: Az Aggtelek-Jósvaföi „Baradla” cseppkőbarlang felmérése (Survey of the AggtelekJósvafö Baradla dripstone cave).- Geod. Közl., 12, 27-40.

Kordos, L., 1984: Magyarország barlangjai (The caves of Hungary).- Gondolat, pp. 326, Budapest.

Lauritzen, S. E. \& Sz. Leél-Össy, 1994: Előzetes koradatok egyes baradlai cseppkövekröl Previous age data about some dripstones of Baradla Cave).- Karszt és Barlang, I-II, 3-8.

Láng, S., 1955: Geomorfológiai tanulmányok az aggteleki karsztvidéken (Geomorphological studies on the Aggtelek karst landscape).- Földr. Ért., IV, 1-20.

Less, Gy., 1998: Földtani felépítés.- In: Boross, G. (ed.): Az Aggteleki Nemzeti Park (Geological characterization, Mezőgazda Kiadó, Budapest, 26-66.

Maucha, R., 1930: Az aggteleki cseppkőbarlang vizeinek kémiai vizsgálata (The chemical investigation of the waters of the Aggtelek dripstone cave).- Hidrol. Közl., X, 201-218. 
Móga, J., 1999: The reconstruction of the development history of karstic water network on the southern part of the Gömör-Torna karst ont he bases of ruined caves and surface forms. (The role of the structure and stone structure in the shaping of the karstic landforms of the Szilice Plateau).- Acta Carstologica, 159-174.

Móga, J., 2001: A szerkezet és kőzetfelépítés szerepe a Szilicei-fennsík karsztos felszínformáinak kialakításában.- Karsztfejlődés VI. BDF, Természetföldrajzi Tanszék, Szombathely, 143-159.

Móga, J., 2002a: Felszínalaktani vizsgálatok a Galyaság területén (Geomorphological investigations in the area of the Galyaság).- Karsztfejlödés VII. BDF, Természetföldrajzi Tanszék, Szombathely, 173-186.

Móga, J., 2002b: A tornai Alsó-hegy felszínalaktanának új eredményei (New results of the surface morphology of the Torna Alsó-hegy).- Karszt és Barlang, I-II., 95-104.

Sásdi, L., 1990: Az Aggtelek-Rudabányai-hegység karsztjának földtani fejlődéstörténete (Geological evolution of the karst of the Aggtelek-Rudabánya Mountains).- Karszt és Barlang, 1, 3-8.

Szenthe, I., 1970: Újabb eredmények a Baradla kutatásában (Newer results in the research of Baradla Cave).- Karszt és Barlang II, 63-64.

Szentes, Gy., 1965: Földtani, tektonikai és genetikai vizsgálatok a Baradla- és Béke-barlangban (Geological, tectonic and genetic investigations in the Baradla and Béke caves).- Karszt és Barlang II, 71-78.
Takácsné Bolner, K., Eszterhás, I., Juhász, M. \& S. Kraus, 1989: The caves of Hungary.- Karszt és Barlang, Special Issue, 17-30.

Vass, I., 1831: Az Aggteleki barlang leírása fekete területével, talprajzolatával és hosszába való átvágásával két táblában; (Description of the Aggtelek cave with its ground-plan and longitudinal section) Pesten.

Veress, M., 2008: Adalékok az Aggteleki-fennsík völgyeinek fejlödéséhez (Some data to the valley evolution of the Aggtelek Plateau).- Karszt és Barlang, I-II, 3-12.

Veress, M., 2009: Investigation of covered karst form development using geophysical measurement.- Zeits $\mathrm{f}$. Geomorph., 53, 469-486.

Wagner, M., 1964: Az aggteleki Baradla-barlang fekete színeződésének vizsgálata (The investigation of the black colouring of Baradla cave of Aggtelek).Karszt és Barlangkutatási Tájékoztató, 1, 4-7.

Zámbó, L., 1998: Felszínalaktani jellemzés.- In: Boross G. (ed.): Az Aggteleki Nemzeti Park (Geomorphological characterization), Mezőgazda Kiadó, Budapest, 70-96.

Zámbó, L., Ford, D. \& T. Telbisz, 2002: Baradla barlangi cseppkőadatok a késő-negyedidőszaki klímaingadozások tükrében (Dripstone data of the Baradla Cave with respect to late Quaternary climatic oscillations).- Földt. Közl., 132/különszám, 231-238. 